\title{
ENVIRONMENTAL CHANGE AND CHALLENGE IN THE HIMALAYA. A HISTORICAL PERSPECTIVE ${ }^{1}$
}

\section{Cambio ambiental y desafíos en el Himalaya. Una perspectiva histórica}

\author{
JACK D. IVES \\ Honorary Research Professor, Carleton University, Ottawa, Canada
}

\begin{abstract}
This overview, or retrospective, has two objectives. The first is to demonstrate how the principles of 'mountain geoecology' were applied in an attempt to counteract the political and socio-economic impacts of a major and misguided environmental orthodoxy-the Theory of Himalayan Environmental Degradation (henceforth to be referred to as the 'Theory'). The second is to explore the difficulties of transferring the results of on-going scholarly mountain research into the public and political decision-making process. In this sense the paper should be regarded as a case study of the potentially serious effects of exaggerated and emotionally based responses to orthodoxies founded on assumptions and latter-day myths. A third objective, reserved for the companion paper in this issue, outlines the origins of mountain geoecology and explores how academic research influenced the inclusion of high level concern for mountain problems within AGENDA 21, one of the principal results of the 1992 UN Conference on Environment and Development (popularly known as the Rio Earth Summit) and declaration of 2002 as the International Year of Mountains.

The original environmental orthodoxy (the Theory) has been eclipsed since the turn of the Millennium by a new populist alarm proposing that the current climate warming will cause all the Himalayan glaciers to disappear in the near future. From this it would follow that, as the glacier melt progresses, numerous large glacial lakes, forming as a consequence, would burst and the ensuing floods would annihilate many millions of people. Eventually, as the glaciers disappeared vital rivers, such as the Ganges and Brahmaputra, would wither to seasonal streams heralding further massive loss of life due to desertification and starvation. This current environmen-
\end{abstract}

1 The paper is based on several sources: (1) a presentation made by the author in 2000 in Tokyo; (2) the section "A new perspective for the $21^{\text {st }}$ century" draws heavily from a series of papers by Alford et al, (2011), Byers (2007), and Watanabe et al. (2009). 
JACK D. IVES

tal alarm could be regarded as a present day parallel to the original Theory and will be examined in the final section of the paper.

Between 1970 and about 1985 it was almost universal wisdom amongst scholars and development specialists, as well as conservationists, that the Himalaya were on the brink of environmental, and hence socio-economic and political collapse. This theme of gloom and doom was taken up avidly by journalists, politicians, and diplomats; it influenced the expenditure of large sums of aid and development money, and augmented periodic international confrontations. In concise terms, in the early 1970s an assumed approaching environmental disaster was perceived to be driven by relentless growth in the population of subsistence hill communities and their dependence on mountain forests for fuel, fodder, building materials, and conversion to agricultural land. The assumption of rapid and catastrophic deforestation of steep hillslopes under a monsoon climate (the World Bank predicted that there would be no accessible forest remaining in Nepal by the year 2000) led inexorably to a series of dependent assumptions: increasing soil erosion and worsening landslide incidence; accelerated flooding and siltation on the plains of Gangetic India and Bangladesh; social and political unrest, if not serious armed conflict - the notion of a world super-crisis, considering that the region in question contained about ten percent of the world's entire human population and about thirty percent of its poorest.

As will be emphasized later, none of this all-embracing construct was based on reliable evidence, but it was accepted world-wide as a given. It represents a prime example of the dangers associated with convenient adoption of environmental myths, or environmental orthodoxies, especially where the myth is a Western 'scientific' construct. I characterized it as The Theory of Himalayan Environmental Degradation (Ives, 1985).

Keywords: Environmental degradation, geomorphic hazards, hydrological hazards, glacier fluctuations, Himalaya.

RESUMEN.- Esta perspectiva global, o retrospectiva, tiene dos objetivos. El primero es demostrar cómo se aplicaron los principios de la "geoecología de monta$\tilde{n} a^{\prime \prime}$ en un intento por contrarrestar los impactos políticos y socioeconómicos de una errónea ortodoxia ambiental, la Teoría de la Degradación Ambiental del Himalaya (en adelante referida como la "Teoría"). El segundo es explorar las dificultades para transferir los resultados de la investigación científica en montaña a los procesos públicos de decisión. En este sentido, el artículo debería ser contemplado como un estudio de caso de los efectos potencialmente serios de las exageradas respuestas a las ortodoxias basadas en suposiciones y mitos de última hora. Un tercer objetivo, reservado a otro trabajo publicado en este volumen, subraya los orígenes de la geoecología de montaña y explora cómo la investigación académica influyó en la incorporación de la preocupación por los problemas de la montaña en la AGENDA 21, uno de los principales resultados de la Conferencia de Naciones Unidas de 1992 sobre Medio Ambiente y Desarrollo (popularmente conocida como la Cumbre de Río), y la declaración de 2002 como el Año Internacional de las Montañas.

La ortodoxia ambiental original (la Teoría) ha sido eclipsada desde el cambio de milenio por una nueva alarma populista que propone que el actual calentamiento climático hará que todos los glaciares del Himalaya desaparezcan en un futuro próximo. De ahí puede deducirse que, a medida que la fusión glaciar progrese, numerosos lagos glaciares reventarían y las consiguientes avenidas aniquilarían a millones de 
personas. Eventualmente, tras la desaparición de los glaciares, algunos ríos fundamentales, como el Ganges y el Brahmaputra podrían convertirse en ríos estacionales ocasionando la pérdida masiva de vidas humanas debido a la desertificación y el hambre. Esta alarma ambiental podría ser vista como paralela a la Teoría original, y será examinada en la parte final de este artículo.

Entre 1970 y 1985 se mantuvo la opinión entre los científicos y especialistas en desarrollo, así como entre los conservacionistas, de que el Himalaya estaba al borde del colapso ambiental, socioeconómico y político. Este pesimismo y predestinación fue adoptado ávidamente por periodistas, políticos y diplomáticos, e influyó en la dedicación de grandes sumas de dinero y ayudas. En pocas palabras, a comienzos de los años setenta se asumió la ocurrencia de un desastre ambiental determinado por el crecimiento demográfico de comunidades que dependian de los bosques de montaña para la obtención de energía, forraje, materiales de construcción y expansión de los terrenos agrícolas. La asunción de una rápida y catastrófica deforestación de laderas pendientes bajo clima monzónico (el Banco Mundial predijo que no habría bosques accesibles en Nepal hacia el año 2000) condujo inexorablemente a aceptar otras suposiciones: aumento de la erosión del suelo y acentuación de la incidencia de los deslizamientos; incremento de la magnitud y frecuencia de las avenidas y del transporte de sedimento en las llanuras del Ganges en India y Bangladesh; conflictividad social y política, cuando no serios conflictos armados, es decir, la noción de una supercrisis mundial, teniendo en cuenta que la región en cuestión contiene alrededor del 10 por ciento de la población mundial y alrededor de la tercera parte de los más pobres.

Como se pone de relieve a continuación, ninguna de esas ideas se basaba en evidencias fiables, pero fueron aceptadas mundialmente como un hecho. Representan un ejemplo claro de los peligros asociados a la adopción de mitos u ortodoxias ambientales, especialmente donde el mito es una construcción "científica" del mundo occidental. Yo la definí como la Teoría de la Degradación Ambiental del Himalaya (Ives, 1985).

Palabras clave: Degradación ambiental, riesgos Geomórficos, riesgos hidrológicos, fluctuaciones glaciares, Himalaya.

\section{Introduction}

It was my privilege, in 1978, to initiate the first mountain research programme of the Tokyo-based United Nations University (UNU). The programme initially embraced both the mountains of Northern Thailand and the Nepal Himalaya. It led to an enduring partnership with Professor Bruno Messerli, Bern University, and promoted an expanding research team that included scholars and students from Nepal, India, Bangladesh, China, Bhutan, Thailand, Japan, Switzerland, United Kingdom, Australia, New Zealand, Norway, United States, the Soviet Union, Russia, and Canada.

While this endeavour, courting controversy from the beginning, still continues, its character has changed substantially and it has spread along 
both parallel and diverging paths (Chapman and Thompson, 1995; Forsyth, 1998; Mountain Agenda, 1998; Ives, 2004; Hofer and Messerli, 2006; Thompson et al., 2007). It has expanded since 2000 to respond to a new paradigm of potential disaster derived from the current understanding (and possibly deliberate misunderstanding) of world climate change. Similarly, Hamilton (1985) characterized the forest watershed issues of the 1980s as the Four Ms: myth, misinterpretation, misinformation, and misunderstanding. There has been a considerable array of publication, but for the first decade or so (1980 to 1990) the journal Mountain Research and Development served as the primary vehicle.

There have also been a number of important climaxes in the research process, perhaps the most significant being the international conference held at Mohonk Mountain House, New York State, in 1986, and the resulting publication of proceedings, individual papers, and books. The main themes of this so-called Mohonk Mountain Conference on the 'Himalaya-Ganges Problem' are covered in detail in three publications (Thompson et al. 1986; Ives and Ives, 1987; Ives and Messerli, 1989). The conference demonstrated that the Theory was flawed, if not completely untenable.

As the UNU project reached this veritable threshold it became impossible for us NOT to enter the political arena. First there was the local arena of the subcontinent with its myriad of governmental, bilateral, and international aid and development agencies. Many influential personalities in this powerful group of agencies were uncomfortable with our conclusions and their unavoidable implications. Next there was the broader international arena, and our expanding mountain experience led to the formation, in Bern in 1990, of a small group of scholars calling ourselves MOUNTAIN AGENDA. This undoubtedly spearheaded the inclusion of Chapter 13 (managing fragile ecosystems-sustainable mountain development) into AGENDA 21 during the 1992 Rio de Janeiro Earth Summit (UNCED) (see Ives, 2012, this issue).

Despite the foregoing statements, the seemingly entrenched orthodoxy of Himalayan environmental degradation remained a remarkable force in its continued ability to influence conservation and development policy.

\section{The status of Himalayan environmental research in 1989}

With the publication of the book The Himalayan Dilemma (Ives and Messerli, 1989) the following statements could be made. First, at the overall level, The Theory was seriously flawed, if not absolutely untenable. This was not intended to imply that the Himalaya and subjacent plains were not facing critical environmental and socio-economic problems; they were. Rather, the 


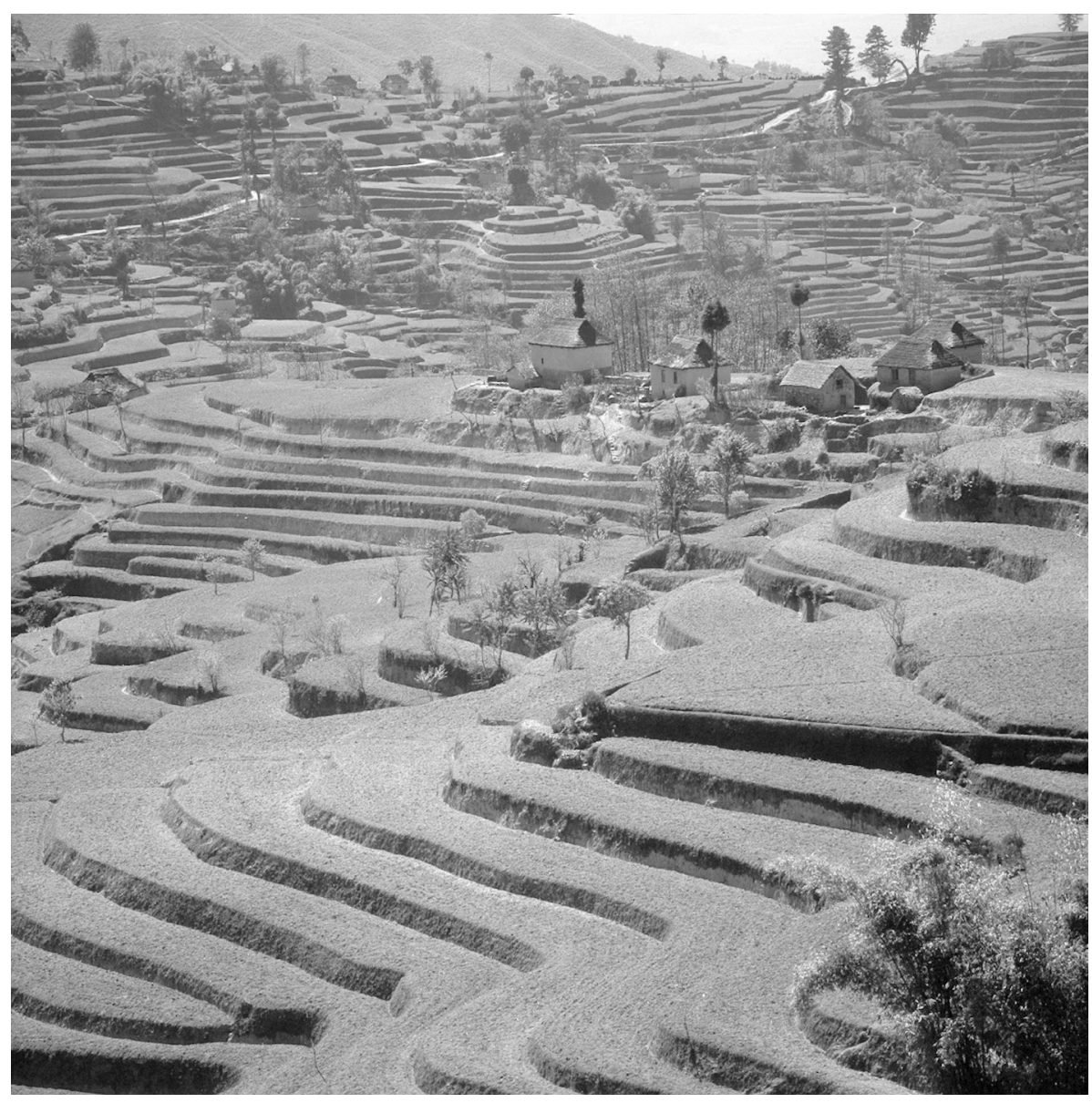

Photo 1. Rain-fed terraces *bari* with maize as the principal crop in the Nepal Middle Mountains * $1980^{*}$. The entire landscape has been transformed by centuries of human ingenuity. Its represents a remarkable example to indigenous soil conservation, yet when the photograph was taken Western "experts" we condemning this kind of activity as leading to massive soil erosion, landsliding, and downstream devastation on the floodplain of the Ganges. 
major cause-effect relationships had been confused by the imposition of a Western 'scientific' construct (The Theory) that was self-serving to a large degree for the aid agencies, conservationist institutions, and regional and distant governments. It had literally seduced thinking and non-thinking people alike by its very nature: elegant simplicity; intellectually satisfying appeal; apparent 'common sense' - the classic case of environmental orthodoxy. The so-called 'ignorant' mountain subsistent farmer (a most convenient scapegoat) had been identified as THE PROBLEM rather than as a significant part of the solution(s).

On a more detailed scale, The Theory had been broken down into eight inter-linked component parts (vicious circles within vicious circles) (Ives and Messerli, 1989: 3-4). Several of these inter-linkages had been refuted absolutely; the credibility of others severely questioned. For example, since it could be shown that deforestation had been occurring for centuries, had peaked in the early twentieth century and, at least in the Middle Mountains, had subsided by 1920-1930, post-1950 population-environmental problems could not be attributed to the cause-effect relationship demanded by The Theory. Similarly, the incidence of soil erosion, landsliding, and down-stream flooding and siltation could not be linked to deforestation by the subsistent mountain farmers (Hamilton, 1987, even protested that the very term 'deforestation' was so fraught with emotion and uncertainty that it should not be used at all). The problem of flooding of the plains of the Ganges and Brahmaputra could not be rigorously analyzed because of absence of data, or because of lack of access to existing data that were held incommunicado by more than one of the riparian states. Regardless, there was no available evidence to support the deduction (assumption) that flooding was any more extensive than a hundred, or three hundred, years ago.

Hamilton (1987) provocatively stated: "It floods in Bangladesh when it rains in Bangladesh." Landslide intensity was shown to be inversely proportional to population density - where population density was high, there was abundant labour for terrace maintenance and repair. Extensive terracing of steep mountain slopes was a massive and effective form of indigenous soil conservation (Photos 1 and 2). Overwhelmingly, most of the mass transfer of weathered material from the mountains and hills toward the Bay of Bengal was a natural phenomenon related to the geo-tectonics of the region: an on-going process for many millions of years. The region is undoubtedly one of the most geophysically unstable in the world. Without this massive natural transfer of material by the Himalayan rivers, Bangladesh and much of northern India and Pakistan would likely not exist; they would be beneath sea level. 


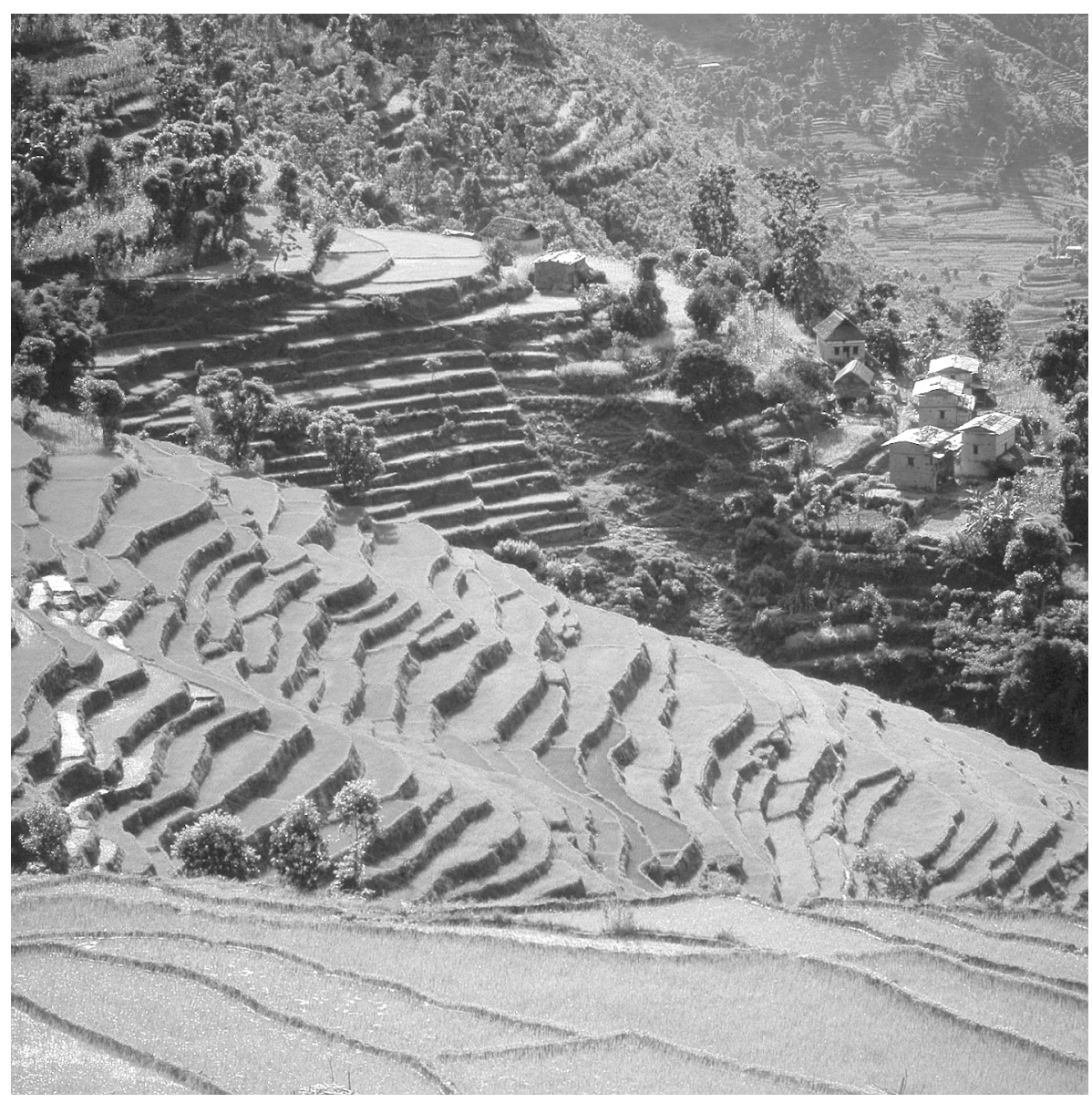

Photo 2. This is an example of Nepal Middle Mountain irrigated terraces *khet ${ }^{*}$ with paddy ${ }^{*}$ rice as the principal crop, often followed by winter wheat or maize ${ }^{*} 1982^{*}$. Note the intricate system of water management. Even more than shown in Photo 1, management of the terraces and control of the flow of water illustrates the arrogance of Western "experts" who blamed the "ignorant" farmers for deforestation and development of unstable agricultural terraces. 
Thus it was shown that available data were insufficient, inadequate, inaccurate, or simply contrived to suit the preconceived policy decisions of the agencies concerned. As Thompson et al. (1986) outrageously stipulated: it was not a question of asking "What are the facts?", but "What would you like the facts to be?" This applied not only to the bio-physical realm, but also to the socio-economic/demographic realm. Women, who constitute an actual majority of the mountain farmers, had been largely ignored in terms of the objectives of aid and development policies and projects. Corruption in government and business circles was rampant. Much of the actual destruction of forests, especially in the Terai, was controlled by government and commercial interests. And, especially discouraging, local wisdom and indigenous ecological know-how, together with village-level institutions for environmental management, were set aside, if not actively discredited. The indigenous farmers had become a convenient scapegoat.

Some especially disturbing findings also need to be emphasized. Western scholars and agency personnel, in some instances, even deliberately falsified reports-the 'end-justifies-the-means' syndrome. The best specific example derives from the Mount Everest region (Khumbu Himal) where it was claimed that hillslopes observed to have been forested in the late-1950s had lost their forests by the late-1970s. These statements were effectively discredited by Byers (1987) using the simple but decisive method of replication of early photographs. Moreover, it is also necessary to record that The Theory, both with and without modification, had been extended far beyond the Himalaya sensu stricto, into Burma, Northern Thailand, and southwest China.

Despite the foregoing, it must be admitted that to argue The Theory is untenable because of inadequate data risked the charge of reductio ad absurdum : if it cannot be proven because of lack of data, how can it be falsified? Nevertheless, the book, The Himalayan Dilemma, was produced as one means of provoking a new generation of more rigorous investigation and as an attempt to bring to the attention of the popular news media (Ives 1991; Pearce 1991) a challenge to the dangers of persisting with the environmental orthodoxy. Nonetheless, we were aware that our work focused too heavily on Nepal and may not be as representative of the wider Himalayan region as we may appear to have implied. At least it set a challenge and demonstrated a number of avenues for future research, pursuit of which should reduce the level of uncertainty and possibly establish several useful certainties. The next section explores research developments of the following decade: some as a direct and intended result of the original United Nations University project; some encouraged indirectly by independent reactions of other scholars and institutions; some entirely serendipitous. 


\section{Himalayan research: 1989-1999}

The Mohonk Mountain Conference had sought to bring together the results of on-going research activities, in addition to our own. Especially relevant was the work of the Nepal-Australia Forestry Project (Mahat et al., 1986 a and b, 1987; Gilmour, 1988; Griffin, 1989), ICIMOD, and further afield, studies by several Indian Hill Universities and the G.B. Pant Institute of Himalayan Environment and Development. In addition, important links with environmental activists (e.g. Sunderlal Bahuguna and the Chipco Movement) helped reinforce an understanding of the perceptions of the hill farmers themselves. All of this had contributed to our examination of The Theory at Mohonk Mountain House and influenced the trends of subsequent research.

Bruijnzeel and Bremmer (1989) and Rogers et al. (1989) concurrently undertook a review of the literature relating to highland-lowland interactions between the Himalaya and the Ganges/Brahmaputra and concluded, in accordance with Ives and Messerli (1989), that the Theory retained little credibility. This challenge to the established orthodoxy of the Theory was placed on a much more rigorous footing subsequently (Hofer 1993; Hofer and Messerli, 2006), amongst several others, and will be discussed below.

Metz (1997), from detailed and reiterated studies in the Middle Mountain forest communities, raised the issue of natural plant succession as a hitherto ignored factor in the 'deforestation discussion'. Metz studied seven littledisturbed stands of temperate forest $40 \mathrm{~km}$ north-northeast of Kathmandu between altitudes of 2,400 and 2,900 $\mathrm{m}$. He demonstrated that the only major canopy dominant that appeared to be regenerating sufficiently to maintain its current population was Tsuga dumosa. He hypothesized that Quercus species were unable to reproduce in individual tree-fall gaps and required a much more severe level of disturbance, such as produced by intense ground fires and large mass wastage occurrences (Metz, 1997:349).

Another research group effort of significance is the University of British Columbia-Bern University joint study of several small watersheds in the Nepal Himalaya (Schreier and Wymann, 1996). The Schreier research team identified for study a remote watershed near the border between Nepal and Tibet. The objective was to assess the human impacts on water and sediment dynamics in the High Himal and to link the processes and their effects through the Middle Mountains to the lowlands. This was complemented by a Messerli-Hofer engagement in the Ganges- Brahmaputra delta (Hofer and Messerli, 2006).

Schreier's group added the Jhikhu Khola watershed in the Middle Mountains and initiated minutely detailed studies over a period of more than five years. These included the collection and analysis of thousands of soil 
samples, determination of the impacts of farming activities, and application of sophisticated GIS modelling. One question of critical importance was: how do the episodic rainstorms translate into run-off and sediment dynamics? They concluded that human intervention plays a significant role in sediment transfer at the local scale by redistribution of the losses incurred by cultivation of steep slopes. Wymann (1991) had already demonstrated that soil nutrient content is inversely proportionate to altitude in the Jhikhu Khola watershed whereby the lowest rice paddies have a high nutrient status due to the downslope transfer of sediment from the upper terraces during rainstorms. One corollary of this is that the farmers, with their elaborate indigenous system of retaining and redistributing sediments, maintain an important command over their fields. Only in extreme rainfall events was it possible to obtain some measurable response beyond the limits of the small watershed. This provided further support for diffusing the 'myth' of human impact on a Himalayan scale.

Schreier and Wymann (1996) had concluded that: "As we moved from a first order stream system... to the complexity of the Himalayan foothills we were overwhelmed by the scale of the processes, and the question of human impact simply fades away by the sheer magnitude of the natural processes."

Independently, and as part of a project initiated by the Royal Geographical Society, $\mathrm{Wu}$ and Thornes (1995) undertook a geomorphological study of Middle Mountain terrace irrigation. They determined that terracing did not change the hydrological behaviour of the hill slopes and that the effects of human impacts were positive rather than negative. They showed that individual terrace failures during torrential monsoon downpours did not contribute any sediment to the downslope nor significantly augment stream flow beyond the experimental watershed. The mechanisms of the large-scale terraced slope failures, which involved dozens of terraces, were much more complicated. Even on such a scale of failure, however, farmers who managed terraces and irrigation canals on land naturally prone to erosion and failure could repair most of the damage and induce lower sediment yield and reduce overland flow. Nevertheless, the problem of extrapolation to a larger region remained to be resolved.

The research by $\mathrm{Wu}$ and Thornes (1995) was followed up by more intensive efforts sponsored by the Royal Geographical Society; they also concentrated on the Middle Mountains in the vicinity of Kathmandu and extended over several years. The results provided additional confirmation that The Theory was untenable. Gerrard and Gardner (1999) concluded that "large-scale landsliding is not a major problem in the study area" and that while well over half of the surface area had experienced landsliding, the 
majority of failures were extremely old and part of the natural evolution of the mountain slopes. In another article (Gardner and Gerrard, 2003) they explained that "estimates of total soil losses are significantly less than the hypothetical figures quoted in the past."

At higher altitudes again, Watanabe (1994) demonstrated that mass transfer induced by over-grazing and yak-trampling close to and above treeline was restricted to the immediate slope; the mass movements simply redeposited the weathered material and nothing measurable entered even the first order drainage.

From the Ganges-Brahmaputra delta, related meso- and macro-scale conclusions were drawn (Hofer and Messerli, 2006). These results, in part, were anticipated by Hofer's (1993) study of possible hydrological changes of the rivers Sutlej, Beas, Chenab, and Jhelum, major tributaries of the Indus. This led to the understanding that, with the available data, it was not possible to demonstrate any significant changes in these rivers that did not yield to explanation by associated climatic processes: that rainfall events on the floodplains themselves were extremely important as cause of flooding.

The research in Bangladesh produced an array of significant insights. First, Hofer and Messerli (2006) posed a number of leading propositions and questions:

1. An understanding of the different facets of flooding in Bangladesh was vital for major future decision-making for mitigation of the hazards to life and property on the floodplains.

2. If Himalayan subsistence farmers continued to be identified as the cause of the flooding in the lowlands, the potential for serious political problems would remain.

3. If reporting of the floods by the news media remained superficial, based on the prevailing myths, and did not go beyond slogans and politically biased headlines, the public would not be able to identify the real problems and priorities of the affected population.

4. Understanding floods and hydrological processes in Bangladesh posed a serious scientific challenge, and many questions remained unanswered.

The study involved many integrated approaches: assessment of available historic flood data and changes in river courses by examination of available documentary information back into the nineteenth century; analysis of all available hydrological and climatic data; application of socio-economic questionnaires. The authors' conclusions (Hofer and Messerli, 2006) were nothing short of draconian: 
1. Floods were natural processes of the highland-lowland interactive system, independent of human activities in the upper mountain catchments.

2. Neither magnitude nor frequency of flooding could be shown to have increased over the previous 120 years, although the magnitude of human and property losses was accelerating because of more intensive use of high risk areas.

3. Precipitation and run-off in the Himalaya did not appear to be significant in terms of flooding on the plains. Hamilton's (1987) early assessment, that Bangladesh incurs flooding when it rains in Bangladesh, was largely substantiated.

4. The rainfall patterns of the Meghalaya Hills, and the related hydrology of the Meghna River, appeared to be decisive.

5. The peak discharges on the Ganges and on the Brahmaputra and Meghna rivers were not generally synchronized.

6. Answers to a questionnaire demonstrated that the local farmers ranked river channel erosion, dry season low water, and cyclones in the Sunderbans higher than monsoon floods in terms of threats to their lives and general well-being.

7. Any approach to the reduction of hazards in the Brahmaputra-Ganges delta required collaboration between all the riparian neighbours. This would never be achieved until the conflicting national, political, ethnic aspirations could be integrated: it would await propagation of a full understanding of the dynamics of the regional highland-lowland interactions.

Above all, it would appear that mega-projects, such as the training of entire river systems by massive input of concrete, steel, and earth, were not the solution. First, they would be too expensive, exceeding the GNP of Bangladesh, for instance, by orders of magnitude; second, there was the potential for many negative consequences of such a course; and third, it was doubtful whether it would ever be technically possible to 'control' such a river as the Brahmaputra, regardless of how much money was devoted to it (see also: Rogers et al., 1989).

Going westward, beyond the limits of Nepal, researchers of the G.B. Pant Institute for Himalayan Environment and Development, and several of the Indian Hill Universities, produced increasingly well documented results that indicated the need for modification of several of the 'Mohonk' generalizations. Road construction, accelerating out-migration of males, unequal treatment of women, increased pressures from tourism, were all contributing to a worsening of the overall environmental situation in the 
Garhwal and Kumaun Himalaya. Similarly, studies by Hoon (1996) and Chakravarty-Kaul (1998) showed the existence of serious environmental problems at high altitude - up to and above the treeline in the Central Indian Himalaya. Here the problem was poorly thought out government policies and actual prejudice toward transhumant Gaddis and Bakrwals. This led to a break-down in the age-long synergism between the transhumant herders and the settled subsistent agriculturalists (Uhlig, 1995) to the detriment of most members of both groups as well as the alpine pastures, the winter grazing areas at low altitude, and along the transfer routes.

Negi et al. (1997), building on the work of Tucker (1987), Richards (1987), and Guha (1989), emphasized the importance of a full historic perspective before interpretation of the prevailing environmental and socio-economic situation in the Central Indian Himalaya. They showed that patterns of land use and forest resource extraction, established by the mid-nineteenth century in former British Garhwal and in the autonomous state of Tehri Garwhal, were central to a full understanding of present-day dynamics. They also demonstrated that the dependence on forests for revenue increased significantly after Independence (1947). Consequently, this accelerated environmental pressures and exacerbated social tensions. This type of study also provided insights into the origins of the Chipko Movement and its consequences.

Rawat and Rawat (1994 a and b) also demonstrated the complexity of accelerated erosion associated with different cover types and changing landuse patterns. This supplemented the earlier work of Bartarya and Valdiya (1989) and Valdiya and Bartarya (1991). Farther west, in Himachal Pradesh, Sharma and Minhas (1993) drew similar conclusions. They indicated the extensive damage to the alpine pastures due to poor management and excessive livestock pressure.

Increasing scholarly and development agency attention was at last being focused on social forestry (Jackson et al., 1998), indigenous knowledge, gender, and the opportunities created by a decentralized system of government. This surge in social science was especially relevant to mountain studies. There was no doubt that in the latter part of the $20^{\text {th }}$ century, the importance of common property management had begun to affect resource use policy decisions extensively in Nepal and elsewhere along the Himalaya. Berkes et al. (1998) and Duffield et al. (1998) demonstrated the reasons for the relatively more stable environmental and socio-economic conditions of the Kulu Valley, Himachal Pradesh, compared with many other sections of the Central Indian Himalaya. Nevertheless, they did point to problems, both in terms of diversity and sustainability of resource use created by the 
replacement of traditional agriculture with orchards and other cash crops, and the heavy use of subsidized pesticides (Berkes et al., 1998:32). They concluded that the contemporary changes in the Kulu Valley supported Shiva's (1993: 7) claim that development policies and prescriptions imported from the West "may be turning this culturally and biologically diverse world into a monoculture." Perhaps even more serious was what Shiva referred to as "monocultures of the mind" as undermining the very local social institutions that are such a positive force for sustainable resource use.

The western Himalaya, Karakorum, and HinduKush were environmentally and geographically beyond the scope of the original UNU project on highland-lowland interactions. Nevertheless, they had been 'willy-nilly' lumped into the Theory of Himalayan Environmental Degradation. Fortunately, knowledge of this complex high mountain area developed rapidly during the 1990s (Hewitt, 19851993 1997; MacDonald, 1996; MacDonald and Butz, 1998). Another source of information derives from the Pakistan-German Karakorum Project under the leadership of Professor Irmtraud Stellrecht (Kreutzmann, 19911993 1995; Schickhoff, 1995; Nusser and Clemens, 1996; Stellrecht, 1998; Stellrecht and Bohle, 1998).

With the progress of this work, as for other areas of the Himalaya (sensu lato), the complexity of the region and its problems were more clearly indicated. Of special interest was the work of the Aga Khan Rural Support Programme and its sensitive efforts to adjust local well-being to face the encroachment of outside pressures that increasingly disrupt the traditional ways of life of the numerous ethnic mountain groups. Kreutzmann (1991 1993 1995) emphasized the many issues facing the peoples and landscapes of Northern Pakistan and adjacent areas. Here regional and world politics and military pressures were major driving forces. The central role of the Karakorum Highway was identified, both in terms of the mountain hazards it confronted (Hewitt, 1993) and its facilitation of foreign intrusions and local out-migration. Another critical facet was the effects of encroaching development on the position of mountain women.

Felmy (1996) and Azhar-Hewitt (1998 1999) derived valuable insights from their examination of the traditional and changing positions of women in several of the hitherto isolated Moslem communities. Hunza, Chitral, Gilgit, have long been part of the mystique of the Great Game, so popularized by Rudyard Kipling. The sensitive treatment of Felmy (1996), following her sojourn in a Hunza village, and Azhar-Hewitt's attempts to lay bare the inadvertent damage that was occurring, especially to the status of women, and hence the basic fabric of society, regardless of sincere and wellintentioned efforts to aid 'development', were vital to our appreciation of the mountain dynamics of the entire region. 
So far the discussion of post-1989 research had been restricted largely to work undertaken independently by individuals and institutions. They are introduced here because they fitted naturally into the enlarging web of hypotheses and directions that could be traced to the Mohonk Process. The work of Hofer and associates in parts of the Central Indian Himalaya (Hofer, 1993) and Bangladesh (Hofer and Messerli, 2006), however, was a direct continuation of the original UNU project. It all had a specific bearing on the controversy over highland-lowland interactions in the context of the cause and magnitude of flooding in Gangetic India and Bangladesh. It was equally relevant to our understanding of the dynamics of the changing adaptations of the mountain peoples to their environments.

Farther afield to the east, work by Forsyth $(1994,1996,1998)$, Renaud et al. (1998), and Roder (1997), in Northern Thailand, Laos, and Vietnam added detail and reinforced the main Mohonk conclusion that The Theory was insupportable. However, they also demonstrated that, as more studies were undertaken, the complexity of the entire region could be shown to defy simple analysis. An overview of the topic, 'montane mainland Southeast Asia in transition' was provided by the volume edited by Rerkasem (1996).

Additional direct extensions of the original UNU project included investigations in Yunnan, southwestern China (Ives and He, 1996; Sicroff, 1998; Swope et al., 1997) and in Tajikistan (Badenkov, 1997; Cunha, 1994, 1997).

The research in Yunnan was initiated in parallel with the main project in the Nepal Himalaya and early conclusions were inserted into The Himalayan Dilemma (Ives and Messerli, 1989). These early conclusions from the Lijiang, Yulong Xueshan area of northwestern Yunnan supported the primary results of the main project. Subsequent field investigation (1993, 1994, and 1995) revealed an unfolding degree of complexity. The prevailing assumptions, that simple massive deforestation after 1950 (and now, in part, attributed to the policies of Mao Zedong and the Gang-of-Four) leading to increased soil erosion, and downstream accelerated flooding and siltation, were categorized as incorrect. While the later work substantiated this in general, in detail the situation proved to be more complicated. The emerging pattern was one of natural and human/political dynamism, such that innumerable small mountain areas were observed to be responding differently, both in time and space over the preceding 50 to 70 years, to different forms of resource use and environmental pressures (Ives and He, 1996; Sicroff, 1998; Swope et al., 1997). These were driven largely by the dynamics of China's domestic politics. Between 1994 and 1998 the rapid increase in mass tourism, encouraged by the provincial and central governments, and the politicization of forest resource usage, emerged as the over-riding impacts. It raised the question: can the potential advantages of tourism, in terms of environmental stability and 
welfare of extremely poor mountain ethnic minorities, be managed so that they outweigh the severe threats of environmental and socio-economic disruption?

This outline of pre- $21^{\text {st }}$ century research developments in the Himalayan region (sensu lato) is neither exhaustive nor final. However, it serves to emphasize some of the research trends that had a direct relationship to the 'Mohonk Process'. Was it possible at that stage to make a formal evaluation of what had been accomplished? The broad sweep of our 1989 level of understanding had been largely substantiated. The Theory could be dismissed absolutely! Why then did it continue to attract extensive attention in the news media and to influence much mountain policy formulation? Perhaps a simple answer will suffice - we academics had failed to penetrate the news media and the international aid agencies; The Theory retained much of its elegant simplicity, intellectual satisfaction, 'common sense'. It is tempting at this point to quote the revealing dictum of Max Planck:

New scientific truth does not triumph by converting its opponents and making them see the light. It triumphs because its opponents eventually die.

I could have taken a more sinister tack and speculated that 'foreign aid' was never intended to benefit the poor people of the 'developing' countries. Nevertheless, a single major UN agency, FAO, was prepared to publish argumentation to the effect that the earlier stand on the original environmental orthodoxy may have been incorrect (FAO/CIFOR 2005). The actual title is revealing-Forests and Floods: Drowning in fiction or thriving on facts?

Perhaps the five most important conclusions that could be drawn from this discussion did relate back to the Mohonk Conference and The Himalayan Dilemma (Ives and Messerli, 1989):

1. The only generalization that could be made about the Himalaya was that the region was too complex to permit generalization.

2. The poor mountain people had been wrongly identified as THE PROBLEM; rather they were an essential component, if not the main component, of the solution(s).

3. There was NO single Himalayan problem and, therefore, NO single solution; there were numerous problems and numerous potential solutions.

4. Some of the uncertainty had been eliminated or reduced; additional uncertainty had been uncovered.

5. The problems were not primarily environmental; they were socioeconomic and, above all, political. 


\section{A new perspective for the 21 century}

The early years of the new millennium, especially when endorsed by the United Nations declaration of 2002 as the International Year of Mountains, opened to great anticipation amongst the informal, and greatly expanded, membership of the Mountain Agenda. Already, however, a new paradigm, or modification of the original Theory of Himalayan Environmental Degradation was emerging. This was tied to the growing awareness that climate warming was undoubtedly having a profound impact on the Earth's environment at large and on glacierized mountains and the polar regions in particular. In this context, the Himalaya were brought into sharp focus.

The New Scientist, in its very celebration of the International Year of Mountains (Pearce, 2002), published an alarming statement attributed to Dr John Reynolds's work on a rapidly enlarging glacial lake in the Nepal Rolwaling Himalaya:

“...the $21^{\text {st }}$ century could see hundreds of millions dead and tens of

billions of dollars in damage..."

due to the outbreak of glacial lakes. While Pearce may be accused of misquoting and exaggeration, such remarks in an international journal are highly disturbing - indicating the likelihood of many more deaths than brought about by World War II. This remark is especially potent considering that Dr Reynolds has denied having made the statement.

The New Scientist report was quickly followed by an article in The Times of London (Pearce, 21 July, 2003) commenting on a scientific conference at the University of Birmingham (UK) and stating that:

“...Himalayan glaciers could vanish within 40 years... 500 million

people in countries like India could be at risk of drought and starvation..."

This piece of hyperbole was attributed to Professor Syed Hasnain, a wellknown glaciologist, who was also quoted as saying that "... the glaciers of the region [Central Indian Himalaya] could be gone by 2035." Hasnain has publicly denied that he ever made such a definitive statement. Nevertheless, a similar claim mysteriously found its way into a vital report by the Intergovernmental Panel on Climate Change (IPCC) (Cruz et al. 2007: 493):

Glaciers in the Himalaya are receding faster than in any other part of the world and, if the present rate continues, the likelihood of them disappearing by the year 2035 and perhaps sooner is very high if the Earth keeps warming at the current rate. Its total area will likely shrink from the present $500,000 \mathrm{~km}^{2}$ to $100,000 \mathrm{~km}^{2}$ by the year 2035 . 
These outrageous statements, the final one with its self-contained contradiction, and widespread public reaction to them, had a serious impact on the International Conference on Climate Change held in Copenhagen in December, 2009. Not only were they directly used by the institutional/industrial opposition to the concept of climate change and its causes, as well as by the more rabid environmentalists, they were spread world-wide through the news media and on the Internet. One of the seemingly logical extensions was that once the glaciers had all disappeared the great rivers, assumed to be overwhelmingly dependent on the glaciers for their annual runoff (Ganges, Brahmaputra, Indus, Yangtze, and others) would either dry up or be reduced to seasonal streams, thus bringing more death through drought and starvation to the millions living downstream.

The initial unfortunate error in the lengthy and otherwise responsible IPCC report prompted equally unfortunate reactions prior to the Copenhagen conference. For instance, Shri Jairam Ramesh, Union Minister for Environment and Forests, was quoted in the North India Times (8 September, 2009) from his opening remarks to a scientific conference:

"...the retreat of Himalayan glaciers is not due to Climate Change...

has no scientific evidence and these scenarios are painted by the West."

The article goes on to claim that the order of magnitude of retreat by the Himalayan glaciers is "...a couple of $\mathrm{cm}$ to a couple of metres every year", and that several are actually advancing. This statement is almost as fantastic at the opposite extreme of the ones that it was intended to discredit.

Environment Minister Ramesh has continued to muddy the waters that should separate glaciology from politics with a recent statement in the Hindustan Times dated 8 June, 2011:

The union minister also exhorted ISRO scientists to undertake more such research projects in the country so that propaganda of "Western scientists" can be countered effectively. "Today, science is politics in international debate on climate change and related aspects. Western scientists have less of scientific agenda and more of political agenda".

The outpouring of melodramatic and unsupported statements has been partly over-shadowed by the rapid spread of terrorism and warfare and by a series of actual catastrophes: the Indonesian earthquake and tsunami of December, 2004; the Pakistan-Kashmir earthquake of 2005, the disastrous flooding of Pakistan of 2010; and the Japanese earthquake and tsunami of March, 2011, also leading to serious nuclear hazard. Regardless, the potential impacts of climate warming on the Himalaya and the related doomsday predictions should not be side-tracked. The next section of this paper, therefore, will provide an overview of what can be derived from the data that 
are available on Himalayan glacio-hydrology, supported by rational application of scientific experience. Rapid increase in new glaciological research could result in the need for modification of some of the stipulations presented here, although the principal conclusions should stand.

As this paper was being finalized the latest in the series of outrageous statements was published by the United Nations Development Programme (UNDP) in the form of a 45-minute video with the title: Revealed: Himalayan Meltdown. Because of its widespread distribution and ease of access on the Internet <http://arrowheadfilms.com/channel/himalayan-meltdown/ password "meltdown"> some preliminary remarks are appended.

One of the most serious misrepresentations is the highly subjective juxtaposition of photographs of Imja Lake with scenes of floods ripping through small yowns (not identified): buildings are collapsing and vehicles swept away. While warning of possible loss of life and destruction to infrastructure is a necessary and worthy task, gross exaggeration and misrepresentation can be dangerously counter-productive. Regardless, it is morally unsupportable. The basic arguments that are presented of rapid glacier melt, devastating floods, and drying up of major rivers are fraught with internal contradictions. There is virtually no reference to the fact that the Ganges and Brahmaputra rivers are supplied overwhelmingly by monsoon rainfall and the large amount of available published research is largely ignored. There are many errors of fact: for instance- $40 \%$ of the world's fresh water (probably three orders of magnitude in error) is contained in the Himalaya; Bangladesh is nowhere near thousands of miles from the Himalaya; the Khumbu village of Phortse, located far above the reach of any possible GLOF, is identified as Dingboche. And, ironically, the Indian Minister of Environment and Forests is now photographed assuming extensive glacier melt despite being quoted in the North Indian Times as insisting on glacier retreat of a mere "couple of $\mathrm{cm}$ to a couple of metres every year".

As explained throughout this paper, gross exaggeration can have powerful negative consequences:

It is more from carelessness about truth than from intentional lying that there is so much falsehood in the world

Samuel Johnson, 1778

\section{Climate warming and the glaciers of the Himalaya}

There is no doubt that many Himalayan glaciers are thinning and retreating in part, at least, as a consequence of human-induced climate 
warming. However, the area under consideration is so extensive, complex, and difficult of access that it is unacceptable to treat the Himalaya as a single unit. In comparison to the Alps, and many other glacierized regions, the Himalaya-Karakorum is little known. The general altitude of many of the Himalayan glacier termini is greater than that of the summit of the Matterhorn. Thus, extrapolation to the Himalaya from the extensive data bank and experience accumulated from Alpine studies would be counterproductive. The glacial environments of the Himalaya, largely because of extreme altitudes, must be treated as unique. Furthermore, the lower sections of many of the larger southern slope glaciers have gentle gradients and are covered by thick mantles of morainic debris that have a significant impact on ablation processes.

Despite the limited glacier data available from the Himalaya sensu lato, it is known that glacier thickening and significant advance is occurring in the Karakorum, which may, however, be anomalous (Hewitt, 2005). In other areas, especially in the Indian, Nepal, and Bhutan Himalaya, significant retreat has occurred and some small glaciers at low elevations have completely disappeared during the last several decades (Byers 2007) while, in contrast, some larger glaciers have barely retreated (see below). Even with the limited amount of available data and the total absence of long-term mass balance records, the extreme statements that have suffused the news media must be dismissed as gross exaggerations, if not mischievous falsifications. The discussion here will entail preliminary examination of three separate yet closely related aspects and be restricted to parts of the Nepal Himalaya because of the relatively greater body of available information.

\subsection{Fluctuations of the glaciers of the Khumbu Himal: 1956-2009}

The first glaciological study of the Khumbu Himal was undertaken by Fritz Müller (1959) as a member of the 1956 Swiss expedition to climb Mt Everest and Lhotse. He spent nine months above 5,000 metres, taking hundreds of photographs and completing an extensive glaciological and permafrost reconnaissance. Of particular interest are the early photographs of the Khumbu, Lhotse, and Imja glaciers. Erwin Schneider produced the socalled 'Schneider map', scale 1:50,000, aided by extensive ground photographs using a photo-theodolite. The Müller/Schneider photographs and map provide a vital benchmark for subsequent comparisons. Photoreplication by Byers (2007) shows little visible change in the appearance of the Khumbu Glacier terminus (1956-2007) and extensive retreat of the Imja 


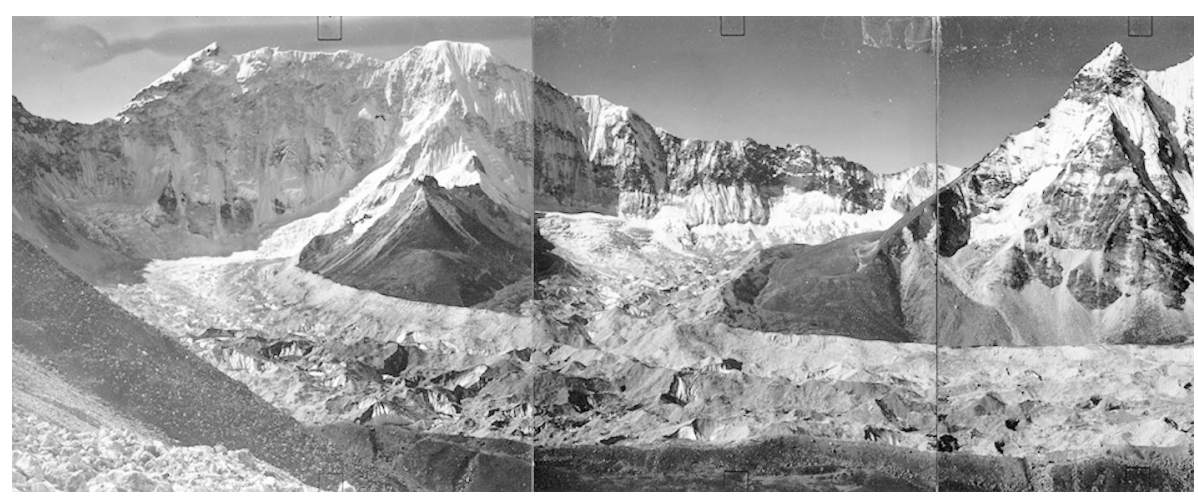

Photo 3. The Imja glacier in 1956, Khumbu Himal, Nepal, from Fritz Müller's collection.

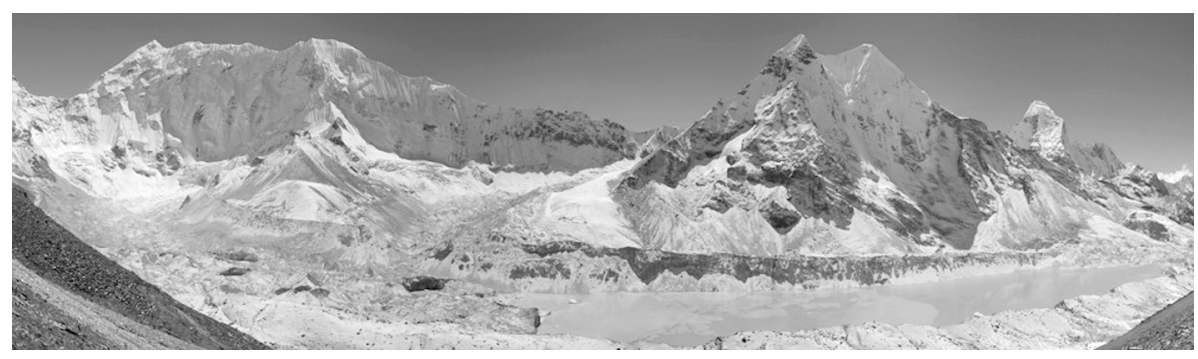

Photo 4. The Imja Glacier photographed by Alton Byers in 2007, showing that in the interval 1956 to 2007, a large lake has developed on the glacier surface. It is now more than two km long and nearly 100 metres deep. 
Glacier, accompanied by the formation of a large lake on its surface. The apparent retreat of the Imja Glacier by more than two kilometres is, in part, an artifice of the lake itself in accelerating melt and retreat of the visible glacier snout. Despite this, both glaciers had thinned considerably. The situation of Imja Lake is discussed in more detail below (Photos 3 and 4).

Byers's replicate photography also demonstrated that several of the smaller, low elevation glaciers had actually melted away completely since the 1950s. Nevertheless, the United Nations Environment Programme reported on an environmental assessment expedition to Khumbu Himal, 16 May to 1 June, 2002:

"...the glacier [Khumbu Glacier] from where Sir Edmund Hillary and

Tenzing Norgay set out to conquer Everest nearly 50 years ago, has retreated five kilometers up the mountain."

It is hardly conceivable how the environmental agency of the United Nations could have published such a statement (Photos 5 and 6).

During the 1960s and 1970s, extensive research was carried out in the Khumbu by a team of glaciologists from Nagoya University, Japan (e.g. Fushimi and Ohata, 1980). More recent work has also been undertaken (e.g., Hambrey et al., 2008). A cursory examination of this readily available body of research would not only have alerted the UNEP environmental assessment expedition to its error, it would have rendered the expense of travelling to the Khumbu unnecessary.

\subsection{The threat of glacial lake outburst floods (jökulhlaup)}

The threat of sudden outburst of glacier lakes in the Himalaya has received increasing attention over the last quarter century. Water from glacier- and snow-melt accumulates in a variety of ways and under different climatic and geophysical circumstances. A glacier may advance so that it blocks an ice-free tributary or main valley to form an ice dam that causes a lake to accumulate behind it. As more water accumulates the increasing hydrostatic pressure may lift, or penetrate, the dam, causing the lake to drain, or the expanding lake may over-top the ice dam to cut a channel through it that rapidly enlarges leading to total or partial lake discharge (see Björnsson, 2010). Dam failure may occur annually or more or less frequently. Lakes also develop on the surface of glaciers, or within them. Another common occurrence is for a lake to form between the terminus of a thinning and receding glacier and the end moraines that had accumulated when it was in a more advanced position. Such moraine-dammed lakes are now forming 




Photo 5. Khumbu Glacier as seen in 1956 *black and white* from Fritz Müller's collection. Comparison with the 2007 colour photograph * photo $6^{*}$ indicates that frontal retreat of the glacier terminus is barely detectable. Although considerable thinning has occurred.

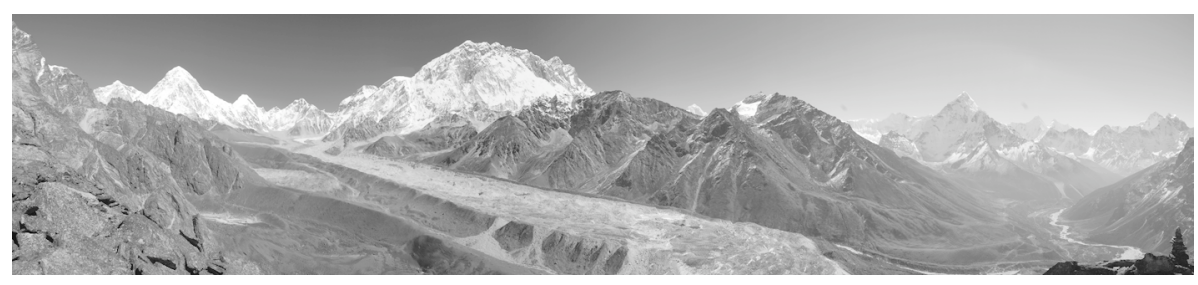

Photo 6. Khumbu Glacier taken by Alton Byers in 2007. 
increasingly as many Himalayan glaciers thin and retreat in response to the current period of climate warming. The supra-glacial lakes, that are also increasing in number and size, often merge with moraine-dammed lakes as the underlying glacier ice slowly melts.

The formation of glacier lakes and their periodic, or one-time only, outbreak are known from many parts of the mountain world but especially from Iceland where local farming populations have struggled against the threat they posed for hundreds of years. The Icelandic term for the phenomenon of catastrophic discharge is jökulhlaup, meaning 'glacier leap'. In the Himalaya the recent term glacier lake outburst flood, abbreviated to GLOF (an ugly word), has come into wide usage. The term jökulhlaup has been used in the standard glaciological literature for over a century and is preferred here. An additional major cause of jökulhlaup in Iceland is sub-glacial volcanic eruption, a phenomenon not reported from the Himalaya.

This overview will focus on the Khumbu Himal and, in particular, on the Imja Glacier located a few kilometres south of Mt Everest, because observations dating back more than 50 years are available (Watanabe et al., 2009). In 1985, a glacier lake, Dig Tsho (Tsho means lake), also in the Khumbu, burst and completely destroyed a nearly completed Austrian aid hydroelectric power station. This led to the initial research reported here (Ives, 1986; Vuichard and Zimmermann, 1986, 1987). Attention was subsequently focused on the Imja Glacier and its supra-glacial lake, Imja Tsho (Mool et al., 2001; Watanabe et al., 2009; Ives et al., 2010; ICIMOD 2011; Lamsal et al., 2011).

\section{Imja Glacier and its rapidly enlarging lake}

The significant lake that was forming on the lower part of Imja Glacier was first noticed in 1984 during the UNU's mountain hazards mapping in the Khumbu (Zimmermann et al., 1986). Dr Bradford Washburn made available high quality vertical air photographs taken during a survey for the National Geographic Society's 1:50,000 scale map of the Mount Everest region. Comparison of the Washburn photographs with the Müller/Schneider information of the 1950s led to the realization that the new lake was expanding rapidly and that it may present a serious hazard for people living downstream and to the thousands of mountaineers and trekkers and their support staff who make their way annually to the Mount Everest base camp along the trail below.

Study of the Imja Glacier and lake continued from 1986 (Hammond, 1988; Watanabe et al., 1994, 2009; Hambrey et al., 2008; Fujita et al., 2009) onwards culminating in extensive geophysical surveys and assessment of downstream 
vulnerability (Ives, et al., 2010; ICIMOD 2011). The most recent dimensions of the lake are: surface area, $1.012 \mathrm{~km}^{2}$; length, $2.2 \mathrm{~km}$; maximum depth, $96.5 \mathrm{~m}$; volume, 35.5 million $\mathrm{m}^{3}$. Yet its level had fallen $37 \mathrm{~m}$ by 2006 and remained stable until last surveyed in 2009. Its remarkable expansion was initially considered an indication of a rapidly growing hazard. The current estimate is that the threat of an imminent jökulhlaup needs to be down-played.

Although Imja Tsho originated as an entirely supra-glacial lake from the amalgamation of a series of small surface ponds, it is suspected that much of the underlying glacier ice has melted completely while some may persist beneath the lake waters. Thus the lake could be classified as part frontal and part supra-glacial. This pattern of development is assumed for the mode of formation of all, or most, of the larger glacial lakes in the Nepal Himalaya.

In 1997 the threat of an imminent jökulhlaup from Tsho Rolpa in the adjacent Rolwaling watershed to the west was widely publicized in Nepal. This resulted in various efforts to lower its level by artificial means. At the same time large numbers of people living downstream were forced to temporarily evacuate. The lake was eventually lowered by three metres in 2002; no jökulhlaup has occurred since. However, this episode touched off a determined effort to identify other dangerous locations (Mool et al., 2001), and also to much of the over-dramatization referred to above.

\section{What are the actual hazards associated with the Imja Glacier?}

An assessment of the current instability of Imja Tsho must take into account several inter-related factors. The moraine-covered dead-ice zone between the western margin of the lake and the outermost section of the end moraine is approximately 700 metres across and lake expansion in this direction has been reduced to $6 \mathrm{~m} / \mathrm{yr}$. A crude extrapolation would imply that the lake would not penetrate the end moraine for more than 100 years: not a particularly reliable projection. However, much of the lake bed is well below the level of the spillway where it cuts through the end moraine. Seepage of lake water through the dead-ice zone cannot be ruled out although several inspections have not uncovered any evidence of seepage.

The lake attained its maximum width in 1984 when it reached the base of the high and steep lateral moraines. They rise up to 60 metres above the 2006 lake surface and the ground surface beyond them is also considerably above lake level. The possibility of a massive rock fall or debris flow into the lake from the steep proximal slopes and production of a surge wave sufficient to reach and break through the end moraine was considered and dismissed as a 
remote possibility. There remains the prospect of an ice cascade into the lake from the cliffed glacier front which is now more than 40 metres in height. Any such surge wave would have to travel at least $2.2 \mathrm{~km}$. With continued lake expansion up-glacier even this source of possible instability is being progressively reduced.

Finally, in the event of the end moraine being breached by any of the above mentioned processes the rate and volume of lake drainage cannot be estimated. Glacial lake drainage does not have to be massive and instantaneous and, as noted above, Imja Tsho has already fallen in level by 37 metres. (For a more extensive assessment of Imja Lake and other glacial lakes in Nepal, see Watanabe et al., 2009; ICIMOD 2011; Lamsal et al., 2011).

The overall conclusion is that the potential imminent danger from Imja Tsho is not significant and, if the lake level continues to fall, will diminish. One of the sources of error in earlier predictions of catastrophic drainage was that they were based solely on rate of lake expansion and total lake area. Even so, the wilder predictions, such that cities on the Ganges could be inundated, are beyond the threshold of credibility. Jökulhlaup damage and loss of life has undoubtedly occurred in the recent past in the Himalaya. However, the actual scale of the losses, while certainly not to be taken lightly, has been orders of magnitude lower than popular alarms. The outbreak of Dig Tsho in 1985, caused by an ice avalanche falling into the lake and creating a surge wave, is an example. Although it did destroy the Austrian aid hydro-electricity facility this never should have been built in the location chosen for it. Furthermore, it was known that Dig Tsho, a few kilometres upstream, was close to overtopping its end moraine dam for at least two years prior to the jökulhlaup. Four or five Sherpa lives were lost, some 30 houses and 14 traditional bridges were destroyed. News media reports of this event, which was well studied immediately after the occurrence (Vuichard and Zimmermann 1987), still provided figures for loss of life an order of magnitude too high.

The general conclusion is that glacial lakes in the Nepal Himalaya and farther afield do pose a serious risk and that risk will increase if climate warming continues over the next decades. Nevertheless, it is not possible, given existing knowledge, to make precise predictions. This does not mean that a catastrophic outburst could not happen in the very near future (even tomorrow), neither does it justify the current spate of over-dramatization. Careful and routine monitoring, with extensive application of remote sensing techniques, installation of early warning systems, and over-flights of critical locations, become the most practical approaches (ICIMOD 2011). Nevertheless, it is imperative that local knowledge be incorporated into any such survey. Much traditional knowledge is often lost because of Western 
ignorance. The Sherpas, for instance, as the Icelandic farmers, have acquired much practical knowledge and indeed have their own word (chhu-gyümha) for jökulhlaup.

\subsection{The role of glaciers in the hydrological regime of the Nepal Himalaya}

A study of the relationship between streamflow and glacier melt in the Nepal Himalaya was undertaken by Alford et al. (2011, forthcoming). The primary objective was to develop a methodology that would provide a realistic assessment of the contribution of glacier melt-water to streamflow under the existing limitations of available data. Water and energy budget principles were combined with area-altitude digital elevation models to reflect the influence of altitude and surface area in determining variations in mass and energy exchange. The mesoscale models developed as a result of this study were designed to reflect a fundamental characteristic of mountainous regions- that virtually all properties and processes vary with altitude. At the same time, most of the information available for most mountainous regions are gross aggregates of climatic and hydrologic data extrapolated from lowland stations.

There are three major tributaries of the Ganges River with headwaters in the Nepal Himalaya; from east to west, the Sapta Kosi, the Narayani, and the Karnali river systems. There are a number of gauged catchment basins within each of the three river systems which provided the data used in the study.

Selections were based on two criteria: (1) that the drainage basins were glacierized; and (2) that they had a hydrometric station measuring streamflow. Period-of-record streamflow data published by the Nepal Department of Hydrology and Meteorology were used (DHM, 1988). Nine catchment basins provided sufficient data to justify the analysis. They contain more than $70 \%$ of the total glacier surface area of Nepal.

Orographic streamflow gradients were estimated by plotting mean basin specific runoff in millimetres against mean basin altitude. Based on these gradients, runoff was estimated for $1,000 \mathrm{~m}$ altitudinal belts in each basin. It was found that the maximum runoff values occur between 3,000 and 4,000 m, and minima at the higher and lower extremes. In other words, the greatest precipitation occurs between 3,000 and 4,000 m, well below the lowest permanent ice and snow. The best correlation between calculated and measured runoff was obtained using two separate data sets, one for the Narayani and Sapta Kosi basins, the other for the Karnali basin in western Nepal. The maximum specific discharge value for the two eastern basins was 
slightly above $2.8 \mathrm{~m}$., that for the Karnali basin was approximately $1.3 \mathrm{~m}$. It is assumed this difference is caused primarily by a weakening of the summer monsoon from east to west along the Himalayan front.

\section{Glaciers of the Nepal Himalaya}

It has been estimated that there are approximately 3,250 glaciers in the Nepal Himalaya, occupying an area of about $5,000 \mathrm{~km}^{2}$ with a volume of some $480 \mathrm{~km}^{3}$ of ice. The glaciers cover about four per cent of the total 147,000 $\mathrm{km}^{2}$ surface area of Nepal and are located in the higher parts of the Himalaya. Most occur between 4,000 and 6,000 m (Mool et al., 2001). Very few glaciers have been studied in any detail and there are no long-term mass balance data. It is significant that the estimated total volume of ice is roughly equivalent to a single year's mean annual flow of the Ganges at the Farraka Barrage, close to India's frontier with Bangladesh. Annually, Nepal contributes an estimated $40 \%$ of the flow of the Ganges, the Indian Himalaya contribute an estimated $10 \%$, and the remainder comes from tributaries flowing in from the south, plus the direct contribution of intense monsoon precipitation onto the extensive area of the lower Ganges basin.

For development of the glacier budget model used in the Alford et al. (2011) study, glaciers were assumed to consist of two distinct zones: an upper accumulation zone and a lower ablation zone. It was further assumed that the altitude dividing these two zones coincided approximately with the mean altitude of the summer-season $0^{\circ} \mathrm{C}$. isotherm (July-Sept.). While technically this is not the Equilibrium Line Altitude (ELA), it serves as an approximate surrogate where comprehensive information on its exact altitude is not available. It was also assumed that no significant melting occurs at any time above the ELA and all melt-water is produced from the ablation zone.

Estimates of glacier ice melt (ablation) as a component of annual streamflow were based on the area-altitude hypsometry of the ablation zone in the nine study basins. Glacier melt was estimated, based on the concept of the ablation gradient that defines the vertical budget gradient between the ELA and the glacier terminus. The area-altitude hypsometry of the glaciers in each gauged catchment was determined for $100 \mathrm{~m}$ altitudinal belts from digital elevation models based on Satellite Radar Topography Missions (SRTM) data (Rabus et al. 2003) combined with glacier areas taken from Mool et al. (2001). As a first approximation, the ELA was set at 5,400 m, the mean altitude of the $0^{\circ} \mathrm{C}$. isotherm, determined by extrapolation at a rate of $1^{\circ} \mathrm{C} / 160$ metres from the available lower altitude temperature data. This process averages the yearto-year variations. 
Values of the ablation gradient reported in the literature range from 0.2 $\mathrm{m} / 100 \mathrm{~m}$ at $80^{\circ} \mathrm{N}$ latitude to nearly $2.0 \mathrm{~m} / 100 \mathrm{~m}$ near the equator. At $30^{\circ} \mathrm{N}$, the generalized latitude of the Nepal Himalaya, correlations between the gradient and latitude suggest a value of approximately $1.4 \mathrm{~m} / 100 \mathrm{~m}$ (Haefeli, 1962) which Alford et al. (2011) used for their study. Until tested by additional field measurements, they considered it a first approximation that will vary somewhat with location and aspect.

An analysis of the existing hydrological and glaciological data with the models developed during the study indicates that glacier melt-water does not make a significant contribution to the rivers flowing from the Nepal Himalaya. Their contribution to total streamflow of the basins in which they are situated varies widely among basins, from between $20 \%$ and $30 \%$ in the Budhi Gandaki basin to about 2\% in the Likhu Khola basin. The overall average is $10 \%$ which represents only about $4 \%$ of the total mean annual estimated volume $\left(200,000\right.$ million $\left.\mathrm{cu}^{3}\right)$ for all the rivers of Nepal. From this it follows that the overwhelming volume of the major rivers of the Nepal Himalaya is derived from rainfall associated with the southwest monsoon. Furthermore, the contribution of glacier melt is inversely proportional to location in a basin in relation to its glaciers. This relationship decreases with increasing distance downstream from the glaciers.

From the foregoing discussion it is apparent that the glaciers of Nepal do not contribute significantly to the streamflow of the rivers of South Asia and there are no data to suggest that their future disappearance, even assuming such to occur, could have a major impact. Discussion of the contribution of glacier melt to agriculture on the plains during the pre- and post-monsoon seasons is beyond the scope of the present overview. Nevertheless, these results are in stark contrast to the dire predictions outlined above. The fact that more than $50 \%$ of the glacier surface area of Nepal is located at altitudes where no significant melt occurs at any time of the year also suggests that they are highly unlikely to disappear in the near future.

While comparable analyses of the glacio-hydrology of the other areas of the Himalaya sensu lato are still needed, it is unlikely that the broad conclusions stated above would be substantially changed. An initial investigation by Alford (2011) of the Upper Indus Basin (Western Himalaya, Karakorum, and HinduKush) using the same methods that were employed in the Nepal Himalaya (Alford et al. 2011) supports this contention.

\section{Conclusion: Lessons to be learned}

It should be clear from the foregoing that when academically-based scholarship has relevance to public opinion on serious political matters, great 
care is needed. The transfer of information, conclusions, opinions, and even speculations, from scholarly, peer-reviewed journals to the news media and, more specifically, to officers of aid and development agencies, and especially to political decision makers, is fraught with danger. The scholarly publishing process is often one of raising questions, not of providing irrefutable answers. Scholarship proceeds, or should proceed, as a means of more nearly approaching a qualified 'truth' over time, and this is often accompanied by the overthrow of established 'truths'. The news media has an overriding tendency to seek out drama, if not to create it inappropriately, in order to sell its wares; politicians have short-term perspectives and a binding selfcommitment to return to power. Scholars, perhaps unfortunately, need financial support; consequently some may be tempted to act as journalists themselves in high profile efforts to attract funds. Development agencies also work for their own constituencies so that their visionary objectives can frequently only be discerned "as through a glass darkly".

None of the above is remotely original but, I believe, we must pause to reflect from time to time. Perhaps the celebration of 2012 as the twentieth anniversary of the Rio de Janeiro Earth Summit (UNCED) provides one of those moments. To begin this process of reflection, Forsyth (1998) derived some interesting comments from what he termed the 'Mohonk Process':

Today, it must be a source of great satisfaction to these authors that this approach has been adopted and applied elsewhere in the developing world. Similar deconstructions of environmental crises have been performed on desertification; the 'fuelwood crisis'; and universalizing statements about soil fertility in Africa.

(Forsyth, 1998:108)

He goes on to stipulate that cultural ecological research reveals that environmental change means different things to different people. More critically, he states that policy actors, governments, or aid organizations, for example, shape the image of a perceived environmental crisis by selecting data that match their own policy objectives. As a specific example he explains that critics have accused the United Nations Environment Programme of maintaining out-dated images of 'desertification' in order to justify its own continued existence.

The urgent need to integrate natural and social environmental science was argued forcibly by Forsyth (1998) and in a companion paper by Thompson (1998). Undoubtedly, such integration, as we attempted, albeit in an ad hoc manner while developing the UNU mountain project, should go a long way toward setting minds open to the reception of indigenous wisdom and to appreciate local perspectives (Griffin, 1989). Our realization that hill farmers in Nepal deliberately initiate landslides the more easily to construct irrigated 
terraces (khet) on the soft run-out of earth (Johnson et al. 1982; Kienholz et al. 1983; Gurung 2007), in retrospect could be classed as a critical turning point for establishment of the Mohonk Process. Yet even as the natural and social environmental sciences become increasingly integrated amongst scholars, how can this be transferred into the decision-making process?

One of the attributes of academia, despite its own need for ever more funds, has long been seen as its position of privilege and security such that it can state findings openly. While this attribute also is being increasingly constrained, relatively speaking, academics remain much freer to 'make-anuisance-of-themselves' by publishing uncomfortable 'truths' or by debunking environmental orthodoxies. One serious challenge is getting these results to the attention of the general public.

Thus we must consider that, concurrent with the growth in mountain awareness since the 1992 UNCED conference in Rio de Janeiro, there has been an appalling increase in armed conflict and open warfare in the mountains of the world that is disproportionately destabilizing mountain regions and their peoples.

When the World Mountain Balance Sheet is reviewed as a whole, military assault on mountain peoples (that has been common throughout the Himalaya-Karakorum-Hindu Kush), often legitimized by the state, surely offsets all the progress toward 'sustainable mountain development' that has been made. This absolutely immoral situation, leading to institutionalized torture, rape, murder, genocide, and the accompanying spread of contagious disease (Hewitt, 1997), has also mutilated many mountain environments. We must also consider the so-called drug wars, frequently mountain-based. Nor can we avert eyes and minds from the misguided imposition of Western, or foreign, interventions. These include mega-hydroelectric projects for the benefit of the lowlanders and urbanites often to the cost of the mountain people. We must also more carefully consider the rationale for the imposition of national parks and nature preserves, in terms of the centuries-long use of their natural resources by the local people (now, fortunately, a rare phenomenon), notwithstanding their world-wide importance. Similarly, the uncontrolled spurts of mass tourism with their economic and social disruptions must also be assessed.

Many of these miss-directions could be much more effectively controlled, if not avoided. However, a first step is for the scholar to insert them into any assessment of mountain dynamics. The next step is to disseminate the findings, both traditionally and through whatever is remaining of the responsible news media.

Above all, the totality of the mountain problematique needs to be addressed and publicized. This may be best approached by the provision of resources 
necessary to establish a new scholarly mountain discipline -MONTOLOGYset to bridge the gap between research and its application (Rhoades, 1997 2007). The foundations for this are coming into place, forced by the imperative of AGENDA 21, Chapter 13 and IYM 2002, but much more is needed. Certainly a free-standing montology should have the fortitude to accelerate the challenge to many environmental orthodoxies (the mountain myths). Some of these have done so much damage, including simple loss of time in worsening situations while development agencies and governments continue to pursue the myths with misallocation of resources.

The planned celebrations for this 2012 'twenty-years-after-Rio' should provide an occasion for a renewed surge in effort to achieve sustainable mountain development.

\section{Acknowledgements}

Over the long period covered by this paper the author has received assistance from colleagues too numerous to enumerate individually although the majority are cited in the list of references. Much discussion and privileged access to research by Donald Alford, Richard Armstrong, Alton Byers, Pradeep Mool, Rajendra Shrestha, and Teiji Watanabe, together with their published work, has formed the basis for the section A new perspective for the $21^{\text {st }}$ century. Collaboration with Bruno Messerli, as co-coordinator of the United Nations University mountain project, has been vital throughout the period 1979 to present. Larry Hamilton has provided essential collaboration from the initial planning of the Mohonk Mountain Conference onwards. Sun Honglie, former Vice-President of the Chinese Academy of Science, greatly assisted with the Mohonk Conference and greatly facilitated fieldwork in southwest China. Yuri Badenkov provided valuable support in facilitation of excursions into Tajikistan and the Trans-Causasus. The extensive fieldwork and organization of international conferences, referred to throughout the text has received financial support from many sources; the principal ones are: United Nations University, the Swiss Development Cooperation, The EastWest Center - University of Hawaii, the US National Science Foundation, the academies of science of the Peoples Republic of China, the former Soviet Union, Russia, Tajikistan, the National Planning Commission, Nepal, the Ford Foundation, ICIMOD, Mohonk Mountain House (New York State), and the following universities - Bern, California (Davis), Carleton (Ottawa), Colorado (Boulder). Walther Manshard, both as Vice-Rector of UNU and as Secretary-Treasurer of IGU, and Maurice Strong, in his many senior international positions, have provided indispensable advice, support, and encouragement. 


\section{References}

Alford, D., 2011. Hydrology and Glaciers in the Upper Indus Basin. World Bank Technical Report forthcoming.

Alford, D., Armstrong, R. \& Racoviteanu, A., 2011. Glacier Retreat in the Nepal

Himalaya: The role of glaciers in stream flow from the Nepal Himalaya. World Bank Technical Report forthcoming.

Azhar-Hewitt, F., 1998. All paths lead to the spring: conviviality, the code of honour, and capitalism in a Karakorum village, Pakistan. Mountain Research and Development, 183: 265-272.

Azhar-Hewitt, F., 1999. Women of the high pastures and the global economy: modernization in the Hushe Valley of the Karakorum, Northern Pakistan. Mountain Research and Development, 19 (2): 141-151.

Badenkov, Y., 1997. Violent conflicts in the mountains of the former Soviet Union. IN Messerli, B. \& Ives, J.D. (eds.): Mountains of the World: A Global Priority. Parthenon, London and New York. pp. 113-114.

Bartarya, S.K. \& Valdiya, K.S., 1989. Landslides and erosion in the catchment of the Gaula River, Kumaun Lesser Himalaya, India. Mountain Research and Development, 9(4): 405-419.

Berkes, F., Davidson-Hunt, I. \& Davidson-Hunt, K., 1998. Diversity of common property resource use and diversity of social interests in the western Indian Himalaya. Mountain Research and Development, 18(1): 19-33.

Björnsson, H., 2010. Understanding jökulhlaups: from tale to theory. Journal of Glaciology, Vol. 56, No. 200: 1002-1010.

Bruijnzeel, L.A. \& Bremmer, C.N., 1989 Highland-lowland interactions in the Ganges-Brahmaputra river basin. A review of published literature. ICIMOD, Occnl. Paper No.11, Kathmandu.

Byers, A.C., 1987. An assessment of landscape change in the Khumbu region of Nepal using repeat photography. Mountain Research and Development, 7(1): 77-81.

Byers, A.C., 1997. Landscape change in Sagarmatha Mt. Everest National Park, Khumbu, Nepal. Himalayan Research Bulletin, XVII (2): 31-41.

Byers, A.C., 2007. An assessment of contemporary glacier fluctuations in Nepal's Khumbu region using repeat photography. Himalayan Journal of Science, 4: 21-26.

Chakravarty-Kaul, M., 1998. Transhumance and customary pastoral rights in Himachal Pradesh: claiming the high pastures for Gaddis. Mountain Research and Development, 18(1): 5-17.

Chapman, G.P. \& Thompson, M. (eds.), 1995. Water and the quest for sustainable development in the Ganges Valley. Mansell, London and New York. 208 pp. 
Cruz, R.V., Harasawa, H., Lal, M., Wu, S., Anokhin, Y., Punsalmaa, B., Honda, Y., Jafari, M., LI, C. \& Huu, N., 2007. Asia. Climate Change 2007: Impacts, Adaptation and Vulnerability." Contribution of Working Group II to the Fourth Assessment Report of the Intergovernmental Panel on Climate Change. Cambridge Univ. Press, UK, p. 493.

Cuhna, S., 1994. The applicability of the Biosphere Reserve Model to the Pamir Mountains, Tajikistan. Unpub. Ph.D. dissertation, University of California, Davis, CA.

Cunha, S., 1997. Hunting of rare and endangered fauna in the mountains of post-Soviet Central Asia. Proceedings of the Eighth International Snow Leopard Symposium, Islamabad.

Duffield, C., Gardner, J.S., Berkes, F. \& Singh, R.B., 1998. Local knowledge in the assessment of resource sustainability: case studies in Himachal Pradesh, India, and British Columbia, Canada. Mountain Research and Development, 18(1): 35-49.

FAO/CIFOR, 2005. Forests and Floods: Drowning in fiction or thriving on facts? Forest Perspectives 2, Bangkok, Thailand, and Bogor Barat, Indonesia. FAO Regional Office for Asia and the Pacific and Centre for International Forestry (CIFOR).

Felmy, S., 1996. The Voice of the Nightingale: A Personal Account of the Wakhi Valley Culture in the Hunza. Oxford University Press, Karachi. 109 pp.

Forsyth, T. J., 1994. The use of Cesium-137 measurements of soil erosion and farmers' perceptions to indicate land degradation amongst shifting cultivators in Northern Thailand. Mountain Research and Development, 14(3): 229-244.

Forsyth, T., 1996. Science, myth, and knowledge: testing Himalayan environmental degradation in Northern Thailand. Geoforum, 27(3): 375392.

Forsyth, T., 1998. Mountain myths revisited: integrating natural and social environmental science. Mountain Research and Development, 18(2): 107-116.

Fugita, K., Sakai, A., Nuimura, T., Yamaguchi, S. and Sharma, R.R., 2009. Recent changes in Imja glacial lake and its damming moraine in the Nepal Himalaya revealed by in situ surveys and multi-temporal ASTER imagery. Environmental Research Letter 4: 045205.

Fushimi, H. and Ohata, T., 1980. Fluctuations of glaciers from 1970 to 1978 in the Khumbu Himal, East Nepal. Seppyo, 41: 71-81.

Gardner, R.A.M. and Gerrard, A.J., 2003. Runoff and soil erosion on cultivated rainfed terraces in the Middle Hills of Nepal. Applied Geography, 23: 23-45.

Gerrard, A.J., and Gardner, R.A.M., 1999. Landsliding in the Likhu Khola drainage basin, Middle Hills of Nepal. Physical Geography, 20: 240-255.

Gilmour, D.A., 1988. Not seeing the trees for the forest: a re-appraisal of the 
deforestation crisis in two hill districts of Nepal. Mountain Research and Development, 8(4): 343-350.

Griffin, D.M., 1989. Innocents abroad in the forests of Nepal. An account of Australian aid to Nepalese forestry. ANUTECH Pty. Ltd., Canberra, Australia. 188 pp.

Guha, R., 1989. The Unquiet Woods: Ecological change and peasant resistance in the Himalaya. Oxford University Press, Oxford, UK. 214 pp.

Gurung, S. Manandhar, 2007. Beyond the Myth of Eco-Crisis: Local responses to pressure on land in Nepal. Mandala Publ. Kathmandu, Nepal.

Haefeli, R., 1962. The ablation gradient and the retreat of a glacier tongue. International Association of Hydrological Sciences, Pub. 58: 49-59.

Hambrey, M.J., Quincey, D.J., Glasser, N.F., Reynolds, J.M., Richardson, S.J. and Clemens, S., 2008. Sedimentological, geomorphological and dynamic context of debris-mantled glaciers, Mount Everest region, Nepal. Quaternary Science Reviews, 27: 2361-2389.

Hamilton, L.S., 1985. Overcoming myths about soil and water impacts of tropical forest land uses. IN El Swaifey, W.C. Moldenhauer and A. Lo (eds.), Soil Erosion and Conservation. Soil Conservation Society of America, Ankeny, Iowa, pp. 680-690.

Hamilton, L.S., 1987. What are the impacts of Himalayan deforestation on the Ganges-Brahmaputra lowlands and delta? Mountain Research and Development, 7(3): 256-263.

Hammond, J.E., 1988. Glacial lakes in the Khumbu region, Nepal: An assessment of the hazards. Unpub. Master's thesis, University of Colorado, Boulder, USA.

Hewitt, K., 1985. Snow and ice hydrology in remote high mountain areas: the Himalayan sources of the River Indus. Snow and Ice Hydrology Project, Working Paper No. 1, Waterloo, Ontario, Wilfrid Laurier University.

Hewitt, K., 1993. Torrential rains in the Central Karakorum, 9-10 September 1992. Geomorphological impact and implications for climatic change. Mountain Research and Development, 13(4): 371-375.

Hewitt, K., 1997. Risk and disasters in mountain lands. IN: Messerli, B. and Ives, J.D. (eds.): Mountains of the World: A Global Priority. Parthenon Publishing Group, London and New York. pp. 371-408.

Hewitt, K., 2005. The Karakoram Anomaly? Glacier expansion and the 'Elevation Effects', Karakoram Himalaya. Mountain Research and Development, 25 (4): 332-340.

Hindustan Times, $8^{\text {th }}$ June, 2011.

Hofer, T., 1993. Himalayan deforestation, changing river discharge, and increasing floods: myth or reality? Mountain Research and Development, 13(3): 213-233. 
Hofer, T. \& Messerli, B., 2006. Floods in Bangladesh: History, dynamics, and rethinking the role of the Himalayas. Tokyo, United Nations University Press.

Hoon, V., 1996. Living on the move: Bhotiyas and the Kumaon Himalaya. Sage Publ., New Delhi, London, and Thousand Oaks, California. 254 pp.

Icimod, 2011: Glacial Lakes and Glacial Lake Outburst Floods in Nepal. International Centre for Integrated Mountain Development, Kathmandu, Nepal.

Ives, J.D., 1985. The mountain malaise: quest for an integrated development. IN Singh, T.V. and Kaur, J. (eds.): Integrated Mountain Development. Himalayan Books, New Delhi. 424 pp.

Ives, J.D., 1986. Glacial Lake Outburst Floods and Risk Engineering in the Himalaya. Occnl. Paper, No.5, ICIMOD, Kathmandu.

Ives, J.D., 1991. Floods in Bangladesh: who is to blame? New Scientist, 13 April, 1991, pp. 34-37.

Ives, J.D., 2004. Himalayan Perceptions: Environmental change and the well-being of mountain peoples. Routledge, London. $2^{\text {nd }}$ Edition, 2006: Himalayan Assoc. Adv. of Sci., Kathmandu.

Ives, J.D. \& HE, Y., 1996. Environmental and cultural change in the Yulong Xue Shan, Lijiang District, NW Yunnan, China. IN Rerkasem, B. (ed.): Montane Mainland Southeast Asia in Transition. Chiang Mai University, Chiang Mai, Thailand. pp. 1-16.

Ives, J.D. \& Ives, P. (eds.), 1987. The Himalaya-Ganges Problem. Proceedings of the Mohonk Mountain Conference. Mountain Research and Development, 7 (3): 181-344.

Ives, J.D. \& Messerli, B., 1989. The Himalayan Dilemma: Reconciling Development and Conservation. Routledge, London and New York. 295 pp.

Ives, J.D., Messerli, B. \& Rhoades, R. E., 1997. Agenda for sustainable mountain development. IN Messerli, B. and Ives, J.D. (eds.): Mountains of the World: A Global Priority. Parthenon Publishing Group, London and New York. 455-466.

Ives, J.D., Shrestha, R.B. \& Mool, P.K., 2010. Formation of Glacial Lakes in the Hindu Kush-Himalayas and GLOF Risk Assessment. ICIMOD, Kathamdu.

Jackson, W.J., Tamrakar, R.M., Hunt, S. \& Shepherd, K.R., 1998. Land-use changes in two Middle Hills districts of Nepal. Mountain Research and Development, 18 (3): 193-212 .

Johnson, K., Olson, E.A., \& Manandhar, S., 1982. Environmental knowledge and response to natural hazards in mountainous Nepal. Mountain Research and Development, 2 (2):175-188.

Kienholz, H., Hafner, H., Schneider, G. \& Tamrakar, R., 1983. Mountain hazards mapping in Nepal's Middle Mountains with maps of land use and geomorphic damages (Kathmandu - Kakani area). Mountain Research and Development, 3(3): 195-220. 
Kreutzmann, H., 1991. The Karakorum Highway: the impact of road construction on mountain societies. Modern Asian Studies, 25(4): 711-736.

Kreutzmann, H., 1993. Challenge and response in the Karakoram: socioeconomic transformation of the Hunza, Northern Areas, Pakistan. Mountain Research and Development, 13(1): 19-39.

Kreutzmann, H., 1994. Habitat conditions and settlement processes in the Hindukush-Karakorum. Petermanns Geographisches Mitteilungen. 6 (94): 337-356.

Kreutzmann, H., 1995. Globalization, spatial integration, and sustainable development in Northern Pakistan. Mountain Research and Development, 15(3): 213-227.

Lamsal, D., Sawagaki, T. \& Watanabe, T., 2011. Digital terrain modeling using Corona and ALOS PRISM Data to investigate the distal part of the Imja Glacier, Khumbu Himal, Nepal. Journal of Mountain Science, 8 (3): in press.

MacDonald, K.I., 1996. Population change in the upper Braldu Valley, Baltistan, 1900-1990: All is not as it seems. Mountain Research and Development, 16 (4): 351-366.

MacDonald, K.I. \& Butz, D., 1998. Investigating portering relations as a locus for transcultural interaction in the Karakorum region of Northern Pakistan. Mountain Research and Development, 18(4): 333-343.

Mahat, T.B.S., Griffin, D.M. \& Shepherd, K.R., 1986a. Human impact on some forests of the Middle Hills of Nepal. 1. Forestry in the context of the traditional resources of the state. Mountain Research and Development, 6(3): 223-232.

Mahat, T.B.S., Griffin, D.M. \& Shepherd, K.R., 1986b. Human impact on some forests of the Middle Hills of Nepal. 2. Some major impacts before 1950 on the forests of Sindhu Palchok and Kabhre Palanchok. Mountain Research and Development, 6(4): 325-334.

Metz, J.J., 1997. Vegetation dynamics of several little disturbed temperate forests in east-central Nepal. Mountain Research and Development, 17(4): 333-351.

Mool, P.K., Bajracharya, S.R. \& Joshi, S.P., 2001. Inventory of Glaciers, Glacial Lakes, and Glacial Lake Outburst Floods, Nepal. ICIMOD, Kathmandu.

Mountain Agenda, 1998. Mountains of the World: Water Towers for the 21 Century. Institute of Geography, University of Berne. Paul Haupt AG Berne, Switzerland. $32 \mathrm{pp}$.

Müller, F., 1959. Eight months of glacier and soil research in the Everest region. The Mountain World 1958/59, pp. 191-208, Allen and Unwin, London.

Negi, A.K., Bhatt, B.P., Todaria, N.P. \& Saklani, A., 1997. The effects of colonialism on forests and the local people in the Garwhal Himalaya, India. Mountain Research and Development, 17(2): 159-168. 
North Indian Times, $8^{\text {th }}$ September. 2009.

Nusser, M. \& Clemens, J., 1996. Impacts on mixed mountain agriculture in the Rupal Valley, Nanga Parbat, Northern Pakistan. Mountain Research and Development, 16(2): 117-133.

Pearce, F., 1991. The rivers that won't be tamed. New Scientist, 13 April, 1991, pp 38-41.

Pearce, F., 2002. Meltdown. New Scientist, $2^{\text {nd }}$ November, 176(2367): 44-48.

Pearce, F., 2003. The Times, London, 21 $1^{\text {st }}$ July, 2003.

Rabus, B., Eineder, M., Roth, A. \& Bamler, R., 2003. The shuttle radar photography mission-a new class of digital elevation models acquired by spaceborne radar. Journal of Photogrammetry and Remote Sensing, 57 (4): 241262.

Rawat, J.S. \& Rawat, M.S., 1994a. Accelerated erosion in the Nana Kosi watershed, Central Himalaya, India. Part I: Sediment load. Mountain Research and Development, 14(1): 25-38.

Rawat, J.S. \& Rawat, M.S., 1994b. The Nana Kosi watershed, Central Himalaya, India. Part II: Human impacts on stream runoff. Mountain Research and Development, 14(3): 255-260.

Renaud, F., Bechstedt, H.-D. \& Nakorn, U., 1998. Farming systems and soilconservation practices in Northern Thailand. Mountain Research and Development, 18(4): 345-356.

Rerkasem, B. ed., 1996. Montane Mainland Southeast Asia in Transition. Chiang Mai University, Chiang Mai, Thailand. 497 pp.

Rhoades, R.E., 1997. Pathways Towards a Sustainable Mountain Agriculture for the 21 $1^{\text {st }}$ Century: The Hindu Kush - Himalayan Experience. ICIMOD, Kathmandu.161 pp.

Rhoades, R.E., 2007. Listening to the Mountains. Kendall-Hunt, Dubuque, Iowa. $184 \mathrm{pp}$.

Richards, J.F., 1987. Environmental changes in Dehra Dun Valley, India: 18801980. Mountain Research and Development, 7(3): 299-304.

Roder, W., 1997. Slash-and-burn rice systems in transition: Challenges for agricultural development in the hills of northern Laos. Mountain Research and Development, 17(1): 1-10.

Rogers, P., Lydon, P. \& Seckler, D., 1989. Eastern Waters Study: Strategies to Manage Flood and Drought in the Ganges-Brahmaputra Basin. ISPAN, Irrigation Support Project for Asia and the Near East, Arlington, Virginia, USAID.

Schickoff, U., 1995. Himalayan forest-cover changes in historical perspective: a case study in the Kaghan Valley, Northern Pakistan. Mountain Research and Development, 15(1): 3-18.

Schreier, H. \& Wymann von Dach, S., 1996. Understanding Himalayan processes: shedding light on the dilemma. IN Hurni, H., Kienholz, H., 
Wanner, H. and Wiesmann, U. (eds.): Umwelt Mensch Gebirge. Festschrift for Bruno Messerli. Jahrbuch der Geographischen Gesellschaft Bern, Bd. 59/1994-1996. Berne Switzerland. pp. 75-83.

Sharma, P.D. \& Minhas, R.S., 1993. Land use and the biophysical environment of Kinnaur District, Himachal Pradesh, India. Mountain Research and Development, 13 (1): 41-60.

Shiva, V., 1993. Monocultures of the mind: understanding the threats to biological and cultural diversity. Unpub. Report. International Development Research Centre. Ottawa, Canada.

Sicroff, S., 1998. Approaching the Jade Dragon: Tourism in Lijiang County, Yunnan Province, China. Unpub. Master's thesis, University of California, Davis, California.

Stellrecht, I. ed., 1998. Culture Area Karakorum-Scientific Studies, Part 1: Karakorum-Hindukush-Himalaya: Dynamics of Change. Rüdiger Köppe Verlag Köln. 608 pp.

Stellrecht, I. \& Bohle, H-G. (eds), 1998. Culture Area Karakorum Studies, Part 5: Transformation of Social and Economic Relationships in Northern Pakistan. Rüdiger Köppe Verlag Köln. 429 pp.

Swope, L., Swain, M.B., Yang, F. \& Ives, J.D., 1997. Uncommon property rights in Southwest China: trees and tourists. IN Johnston, B.R. ed.: Life and Death Matters: Human rights and the environment at the end of the millennium. AltaMira Press, Sage Publ. Walnut Creek, California, London and New Delhi. pp. 43-69.

Thompson, M., 1998. The new world disorder: is environmental security the cure? Mountain Research and Development, 18(2): 117-122.

Thompson, M., Warburton, M. \& Hatley, T., 1986. Uncertainty on a Himalayan Scale. Ethnographia, London. 162 pp.

Thompson, M., Warburton, M. \& Hatley, T., 2007. Uncertainty on a Himalayan Scale. Second edition with an introduction by M. Thompson and D. Gyawali, Himal Books, Lalitpur, Nepal. 152 pp.

Tucker, R.P., 1987. Dimensions of deforestation in the Himalaya: The historical setting. Mountain Research and Development, 7(3): 328-331.

Uhlig, H., ed. Kreutzmann, H., 1995. Persistence and change in high mountain agricultural systems. Mountain Research and Development, 153: 199-212.

Valdiya, K.S. \& Bartarya, S.K., 1991. Hydrogeological studies of springs in the catchment of the Gaula River, Kumaun Himalaya, India. Mountain Research and Development, 11(3): 239-258.

Vuichard, D. \& Zimmermann, M., 1986. The Langmoche flash-flood, Khumbu Himal, Nepal. Mountain Research and Development, 6 (1): 90-94. 
Vuichard, D. \& Zimmermann, M., 1987. The catastrophic drainage of a moraine-dammed lake, Khumbu Himal, Nepal: Cause and consequences. Mountain Research and Development, 7 (2): 91-110.

Watanabe, T., 1994. Soil erosion on Yak-grazing steps in the Langtang Himal, Nepal.

Mountain Research and Development, 14(2): 171-179.

Watanabe, T., Ives, J.D. \& Hammond, J.E., 1994. Rapid growth of a glacial lake in Khumbu Himal, Nepal: Prospects for a catastrophic flood. Mountain Research and Development, 14 (4): 329-340.

Watanabe, T., Lamsal, D. \& Ives, J.D., 2009. Evaluating the growth characteristics of a glacial lake and its degree of danger: Imja Glacier, Khumbu Himal, Nepal. Norsk Geografisk Tiddskrift, 63: 255-267.

Wu, K. \& Thornes, J.B., 1995. Terrace irrigation of mountainous hill slopes in the Middle Hills of Nepal: stability and instability. IN Chapman, G.P. and Thompson, M. (eds.): Water and the quest for sustainable development in the Ganges Valley. Mansell, London, pp. 41-63.

Wymann, S., 1991. Landnutzungsintensivierung und Bodenfruchtbarkeit im nepalischen Hugelgebeit Unveroff. Unpub. Doctoral thesis, Universität Bern, Switzerland.

Zimmermann, M., Bichsel, M. \& Kienholz, H., 1986. Mountain hazards mapping in the Khumbu Himal, Nepal. Mountain Research and Development, 6 (1): 29-40. 